\title{
EFEKTIVITAS PUTUSAN MAHKAMAH KONSTITUSI NOMOR 22/PUU-XV/2017 TENTANG BATAS USIA PERKAWINAN
}

\author{
Mia Hadiati ${ }^{1}$, Moody R Syailendra ${ }^{2}$, Luthfi Marfungah ${ }^{3}$, Febriansyah Ramadhan ${ }^{4}$, \\ Monalisa $^{5}$, dan Anggraeni Sari Gunawan ${ }^{6}$
}

\author{
${ }^{1}$ Dosen Fakultas Hukum, Universitas Tarumanagara \\ Email:miah@fh.untar.ac.id \\ ${ }^{2}$ Dosen Fakultas Hukum, Universitas Tarumanagara \\ Email:moodys@fh.untar.ac.id \\ ${ }^{3}$ Mahasiswa Program Doktor Fakultas Hukum, Universitas Brawijaya Jakarta \\ Email : luthfimarfungah10@gmail.com \\ ${ }^{4}$ Mahasiswa Magister Hukum Fakultas Hukum, Universitas Brawijaya Malang \\ Email :mrfebri18@gmail.com \\ ${ }^{5}$ Mahasiswa Magister Hukum Fakultas Hukum, Universitas Indonesia \\ Email : monalisasilitonga02@gmail.com \\ ${ }^{6}$ Mahasiswa Strata Satu Fakultas Hukum, Universitas Tarumanagara \\ Email : anggraeni.205190143@stu.untar.ac.id
}

\begin{abstract}
This paper will discuss how the post-judicial decision of the Constitutional Court has a minimum age of marriage for woman and consideration in the values of human rights. This paper aims to provide an understanding to the public that the importance of paying attention to the age of marriage is a form of protection of children's rights, and as an effort to prevent discrimination against woman. The research method used is a combination of normative legal research and empirical legal research. The research material that will be used in this research includes secondary data and primary data. Primary data were obtained directly from samples / research subjects. While the legal materials for secondary data in this study were obtained from library materials related to the problem. After the verdict of the Constitutional Court at a minimum age is married to a 19-year-old woman in terms of the values of human rights, and this is one form of public awareness and responsibility of the state for the protection and fulfillment of human rights (children's rights and principles of nondiscrimination) and constitutional rights. This issue further looks at the future impact of child marriage for woman can lead to discriminatory actions against woman related to the issue of legal position between men and women who will directly violate children's rights.
\end{abstract}

Keywords: Post MK Decisions, Minimum Married Age, Human Rights

\begin{abstract}
ABSTRAK
Tulisan ini akan membahas bagaimana pasca-putusan Mahkamah Konstitusi usia minimal menikah bagi perempuan dan pertimbangan dalam nilai-nilai hak asasi manusia. Tulisan ini bertujuan: memberikan pemahaman kepada masyarakat bahwa pentingnya memperhatikan usia menikah sebagai salah satu bentuk perlindungan terhadap hak-hak anak dan sebagai salah satu upaya pencegahan tindakan diskriminasi terhadap perempuan. Metode penelitian yang digunakan yakni perpaduan antara penelitian hukum normatif dan penelitian hukum empiris. Bahan penelitian yang akan digunakan dalam penelitian ini meliputi data sekunder maupun data primer. Data primer diperoleh secara langsung dari sampel/subjek penelitian. Sedangkan bahan hukum data sekunder dalam penelitian ini diperoleh dari bahan-bahan pustaka yang berhubungan dengan permasalahan. Hasil penelitian menunjukan bahwa pasca-putusan Mahkamah Konstitusi usia minimal menikah bagi perempuan 19 (sembilan belas) tahun menunjukan sangat sarat dengan pertimbangan nilai-nilai hak asasi manusia, dan ini merupakan salah satu bentuk kesadaran masyarakat dan tanggung jawab negara atas perlindungan dan pemenuhan terhadap hak asasi (hak-hak anak, dan prinsip non diskriminasi) dan hak konstitusi. Persoalan ini lebih jauh melihat kedepan dampak dari perkawinan usia anak bagi perempuan dapat menimbulkan tindakan diskriminasi terhadap perempuan terkait dengan persoalan kedudukan hukum antara laki-laki dan perempuan yang secara langsung akan terjadinya pelanggaran terhadap hak-hak anak.
\end{abstract}

Kata Kunci: Pasca putusan MK, usia minimal menikah, hak asasi manusia 


\section{PENDAHULUAN \\ Latar Belakang}

Pernikahan merupakan hak dasar manusia yang tidak boleh dibatasi dan dikurangi oleh siapapun termasuk negara, hal ini sebagaimana ditegaskan dalam artikel 16 Universal Declaration of Human Rights (Deklarasi Universal Hak Asasi Manusia/DUHAM). Artikel 16 DUHAM: "(1). Men and women of full age, without any limitation due to race, nationality or religion, have the right to marry and to find a family. They are entitled to equal rights as to marriage, during marriage and at its dissolution; (2). Marriage shall be entered into only with the free and full consent of the intending spouses; (3). The family is the natural and fundamental group unit of society and is entitled to protection by society and the State. (Artinya: (1) Laki-laki dan Perempuan yang sudah dewasa, dengan tidak dibatasi kebangsaan, kewarganegaraan atau agama, berhak untuk menikah dan untuk membentuk keluarga. Mereka mempunyai hak yang sama dalam soal perkawinan, di dalam masa perkawinan dan di saat perceraian; (2) Perkawinan hanya dapat dilaksanakan berdasarkan pilihan bebas dan persetujuan penuh oleh kedua mempelai; (3) Keluarga adalah kesatuan yang alamiah dan fundamental dari masyarakat dan berhak mendapatkan perlindungan dari masyarakat dan Negara)"

Kemudian ditindaklanjuti dalam artikel 23 International Covenant on Civil and Political Rights (ICCPR) atau Kovenan Hak Sipil dan Politik, dimana keluarga merupakan suatu kelompok masyarakat alamiah yang berhak untuk dilindungi, dan dalam membentuk keluarga melalui suatu perkawinan harus diakui berdasarkan persetujuan bebas para pihak yang hendak menikah. Artikel 23 Kovenan SIPOL : "(1) The family is the natural and fundamental group unit of society and is entitled to protection by society and the State; (2) The right of men and women of marriageable age to marry and to found a family shall be recognized; (3) No marriage shall be entered into without the free and full consent of the intending spouses; (4) States Parties to the present Covenant shall take appropriate steps to ensure equality of rights and responsibilities of spouses as to marriage, during marriage and at its dissolution. In the case of dissolution, provision shall be made for the necessary protection of any children. (Artinya: (1) Keluarga adalah kesatuan kelompok masyarakat yang alamiah serta mendasar dan berhak dilindungi oleh masyarakat dan Negara. (2) Hak laki-laki dan perempuan dalam usia perkawinan untuk menikah dan membentuk keluarga harus diakui. (3) Tidak ada satupun perkawinan yang dapat dilakukan tanpa persetujuan yang bebas dan penuh dari para pihak yang hendak menikah. (4) Negara Pihak dalam Kovenan ini harus mengambil langkah-langkah yang memadai untuk menjamin persamaan hak dan tanggung jawab pasangan suami istri tentang perkawinan, Dalam halnya berakhirnya perkawinan harus dibuat ketentuan yang diperlukan untuk melindungi anak-anak).

Dengan demikian, dalam pemenuhan hak-hak sipil, negara sebagai pemangku tanggung jawab untuk memenuhi (to fulfill), menghormati (to respect), dan melindungi (to protect) hanya bersifat pasif atau sering disebut dengan istilah negative rights (hak-hak negatif). Artinya, hak-hak dan kebebasan yang dijamin di dalam Kovenan SIPOL tersebut akan dapat terpenuhi apabila peran negara terbatasi atau negara bersifat tidak aktif, apabila negara bersifat aktif, maka hak-hak dan kebebasan dalam kovenan tersebut akan dilanggar oleh negara.

Undang-Undang Nomor 1 Tahun 1974, menyatakan bahwa perkawinan adalah ikatan lahir batin antara seorang pria dan wanita dengan tujuan membentuk keluarga (rumah tangga) yang bahagia dan kekal berdasarkan Ketuhanan Yang Maha Esa. Undang-undang No. 1 Tahun 1974 pada mulanya dimaksudkan untuk mengodifikasi hukum perkawinan yang bersifat nasional, disamping mengunifikasikan hukum perkawinan. Akan tetapi setelah disahkan, bukan hukum perkawinan yang bersifat nasional yang tercapai, melainkan kompilasi hukum perkawinan yang bersifat 
nasional yang belum tuntas dan menyeluruh, sebab Undang-undang Perkawinan masih merujuk dan memberlakukan berbagai peraturan perundang-undangan yang lama yang ada sebelumnya, termasuk ketentuan hukum adat dan hukum agama atau kepercayaan masing-masing yang mengatur mengenai perkawinan dan segala sesuatu yang berkaitan dengan perkawinan. Rumusan ketentuan dalam pasal-pasal Undang-undang Perkawinan mencerminkan teknik kompilasi hukum sebagai modifikasi pelaksanaan unifikasi hukum perkawinan yang bersifat nasional.

Perkawinan adalah ikatan yang sakral di antara pria dan wanita yang diakui secara sosial untuk membangun keluarga, melegalkan/menghalalkan hubungan seksual, melegitimasi dan membesarkan anak, dan membagi peran antara masing-masing pasangan, dengan adanya perkawinan, diharapkan suami dan istri dapat menghadirkan kebahagiaan dan kelanggengan dalam menjalankan perkawinan tersebut, sehingga dalam menjalankan perkawinan dibutuhkan kedewasaan dan tanggung jawab secara fisik maupun mental dari pihak-pihak yang melaksanakannya, oleh karena itu, di Indonesia ditetapkan melalui Undang-Undang No. 1 Tahun 1974 tentang Perkawinan, Batasan umur perkawinan. Walaupun begitu, pada faktanya masih banyak dijumpai perkawinan yang dilakukan oleh anak di bawah umur, atau dapat dikatakan sebagai perkawinan anak. Seperti: pernikahan antara pria dengan inisial MAA usia 16 tahun dengan seorang wanita berinisial DAM yang usianya 14 Tahun yang terjadi pada tanggal 3 Maret 2019 di Kecamatan Soreang, Kota Parepare, Sulawesi Selatan. Pernikahan ini dilaksanakan dengan mengajukan dispensasi ke Pengadilan Agama. Selain itu terdapat pula pernikahan salah seorang cucu Mbah RT di Desa Sawangan Magelang Jawa Tengah, yang masih berusia 15 tahun dengan seorang laki-laki yang berusia 16 tahun. Dengan memilih untuk menikah di usia anak, maka cucu mbah RT tidak lagi melanjutkan sekolah.

Apabila merujuk pada ketentuan Undang-Undang Perkawinan Nomor 1 Tahun 1974 Tentang Perkawinan, batas usia minimal menikah seorang laki-laki 19 tahun dan usia perempuan 16 tahun. Norma ini dipandang selain melanggar hak-hak anak. Untuk itu, pemerhati hak-hak anak melalui gerakan solidaritas berusaha memperjuangkan hak-hak anak melalui judicial review Pasal 7 ayat (1) tentang batas usia minimal 16 tahun. Akan tetapi, putusan Mahkamah Konstitusi (MK) nomor: 30-74/PUUXII/2014 menolak permohonan judicial review pemohon, dengan alasan: penentuan batas usia minimum merupakan kebijakan hukum yang bersifat terbuka (open legal policy), dan MK tidak memiliki kewenangan untuk melahirkan norma baru, sehingga apabila ingin melakukan perubahan hukum, sebaiknya melalui legislative review, perkawinan merupakan hak setiap orang yang tidak boleh dibatasi, negara hanya bersifat mengakomodasi perintah agama. Terkait hal ini, dapat dibaca Putusan MK Perkara Nomor 30- 74/PUU-XII/2014 yang diujikan adalah Pasal 7 ayat (1) UU Perkawinan terhadap Pasal 1 ayat (3), Pasal 28A, Pasal 28B ayat (1), Pasal 28B ayat (2), Pasal 28C ayat (1), Pasal 28D ayat (1), Pasal 28G ayat (1), Pasal 28H ayat (1), Pasal 28H ayat (2), Pasal 28I ayat (1) dan Pasal 28I ayat (2) UUD 1945.

\section{Rumusan Masalah}

Berdasarkan rumusan masalah di atas, maka dirumuskan beberapa permasalahan sebagai berikut: 1. Bagaimanakah dasar pertimbangan hakim dalam memutuskan batas usia minimal perkawinan?

2. Bagaimanakah efektivitas pasca Putusan Mahkamah Konstitusi perihal batas usia minimal menikah bagi perempuan dan pertimbangan dalam nilai-nilai hak asasi manusia?

3. Bagaimanakah fenomena pernikahan usia anak di Indonesia? 


\section{METODE PENELITIAN}

Penelitian ini merupakan perpaduan antara penelitian hukum normatif dan penelitian hukum empiris. Bahan penelitian yang akan digunakan dalam penelitian ini meliputi data sekunder maupun data primer. Data sekunder adalah data yang berasal dari bahan-bahan kepustakaan, sedangkan data primer merupakan data yang diperoleh secara langsung dari subyek penelitian. Melalui penelitian kepustakaan kami mendapatkan data dan bahan hukum data sekunder. Data yang diperoleh dalam penelitian kepustakaan adalah data sekunder berupa kaedah atau norma, asas-asas hukum, kaidah-kaedah hukum, dan sistematika hukum. Sedangkan bahan hukum data sekunder dalam penelitian ini diperoleh dari bahan-bahan pustaka yang berhubungan dengan permasalahan, yang terdapat antara lain di dalam bahan hukum primer, bahan hukum sekunder, serta bahan hukum tersier. Cara pengumpulan data dalam penelitian kepustakaan ini adalah dengan merujuk kepada bahan-bahan yang didokumentasikan. Alat yang dipergunakan dalam penelitian kepustakaan adalah studi dokumen. Dalam penelitian lapangan, data yang diperoleh dalam penelitian lapangan adalah data primer yang diperoleh secara langsung dari sampel/subjek penelitian. Penelitian ini dilakukan di Kantor Urusan Agama Bandung, Kantor Urusan Agama Malang, Pengadilan Agama Negeri Bandung, Pengadilan Agama Malang, Pengadilan Agama Bandung, Pengadilan Negeri Malang, dan Pengadilan Negeri Bandung. Sampel/subjek penelitian dalam penelitian lapangan adalah Ketua atau subjek yang memiliki kewenangan Kantor Urusan Agama Bandung, Ketua atau subjek yang memiliki kewenangan Kantor Urusan Agama Malang, Ketua atau subjek yang memiliki kewenangan Pengadilan Agama Negeri Bandung, Ketua atau subjek yang memiliki kewenangan Pengadilan Agama Malang, Ketua atau subjek yang memiliki kewenangan Pengadilan Agama Bandung, Ketua atau subjek yang memiliki kewenangan Pengadilan Negeri Malang, dan Ketua atau subjek yang memiliki kewenangan Pengadilan Negeri Bandung. Metode pengambilan sampel yaitu purposive sampling. Data yang sudah diperoleh baik data primer maupun data sekunder dianalisis secara deskriptif kualitatif dan hasil penelitian menghasilkan data deskriptif analitis.

Penelitian ini dilakukan dengan menggunakan berbagai pendekatan yang sesuai dengan objek kajian yang akan diteliti. Pendekatan yang digunakan adalah dengan sosiologis, yaitu penelitian berupa studi-studi empiris dan undang-undang. Jenis data yang digunakan antara lain: Pertama data sekunder, yang dikumpulkan melalui dokumen hukum yang ditelusuri. Kedua, data primer yang diambil langsung melalui studi lapangan dengan menggunakan teknik observasi dan wawancara mendalam. Cara pengumpulan data dalam penelitian lapangan ini yaitu dengan cara wawancara dengan sampel/subjek peneliti. Alat pengumpulan data yang digunakan dalam penelitian ini adalah pedoman wawancara.

\section{HASIL DAN PEMBAHASAN}

\section{Dasar pertimbangan hakim dalam memutuskan batas usia minimal perkawinan}

Putusan MK No. 22/PUU-XV/2017 adalah putusan yang berasal dari pengajuan uji materi terhadap pasal 7 (1) UU No. 1 Tahun 1974 tentang Perkawinan yang diajukan oleh Tiga orang perempuan pelaku pernikahan dini, Endang Wasrinah, Maryanti, Rasminah. Permohonan uji materi ini dikabulkan oleh MK dengan munculnya putusan ini. Selain putusan ini, pada tahun 2014 MK juga telah membuat putusan yang berhubungan dengan uji materi tentang usia perkawinan, yaitu Putusan MK No 33-74/PUU-XII/2014. Dua putusan di atas terlihat sama karena pemohonan uji materiil pemohon pada putusan keduannya sama-sama terhadap pasal 7 (1) UU No. 1 tahun 1974 yang berbunyi "Perkawinan hanya diizinkan jika pihak pria sudah mencapai umur 19 (sembilan belas) tahun dan pihak wanita sudah mencapai 16 (enam belas) tahun". Meskipun keduanya putusan tersebut di atas berhubungan dengan gugatan terhadap usia perkawinan, tetapi terdapat perbedaan pokok perkara di antara keduanya. Putusan No 33-74/PUU-XII/2014 berkaitan 
dengan permohonan para pemohon untuk menaikkan usia perkawinan bagi wanita dari umur 16 tahun menjadi 18 tahun. Sedangkan Putusan No. 22/PUU-XV/2017 berkaitan dengan adanya perbedaan batas usia perkawinan yang diberlakukan terhadap anak laki-laki dan perempuan. Para pemohon mengajukan permohonan uji materi agar perempuan memiliki kesamaan di depan hukum (equality before the law) sebagaimana kaum pria dalam usia perkawinan, karena semuanya adalah warga Negara. Oleh karena itu, meskipun berhubungan dengan uji materi usia perkawinan, perbedaan pokok perkara ini menunjukkan tidak adanya pengulangan perkara di MK. Oleh karena itu, Putusan MK No. 22/PUU-XV/2017 mempunyai kedudukan dan kekuatan hukum yang jelas. Alasan pengajuan uji materi pada Putusan MK No. 22/PUU-XV/2017 didasarkan kepada peristiwa pernikahan dini yang betul betul telah dialami oleh ketiga pemohon yang mengajukan permohonan uji materi. Mereka telah dipaksa untuk melakukan pernikahan bawah umur oleh keluarga mereka. Sebagai anak perempuan pemohon I dinikahkan pada umur 14 tahun dengan seorang duda beranak satu. Sementara itu, pemohon II dinikahkan pada umur 14 tahun dengan pria berumur 33 tahun. Sedangkan pemohon III dinikahkan pada umur 13 tahun dengan pria berumur 25 tahun. Pemaksaaan perkawinan ini dilakukan kepada mereka dan tidak dilakukan kepada saudara lakilaki mereka.

Menurut para pemohon, salah satu faktor yang menyebabkan pernikahan dini yang meraka alami ini disebabkan oleh adanya perbedaan ketentuan usia minimal perkawinan bagi laki-laki dan perempuan yang ada dalam pasal 7 ayat (1) UU No. 1 Tahun 1974 yang berbunyi: "Perkawinan hanya diizinkan jika pihak pria sudah mencapai umur 19 (sembilan belas) tahun dan pihak wanita sudah mencapai umur 16 (enam belas) tahun”. Pasal ini jelas membedakan batas usia perkawinan antara laki-laki dan perempuan. Ketentuan yang berbeda ini berakibat kepada perlakuan yang diskriminatif terhadap perempuan. Menurut para pemohon, pasal ini bertentangan dengan UUD 1945 pasal 27 ayat (1) yang memberikan hak dan kedudukan yang sama bagi semua warga Negara didepan hukum (equality before the law). "Segala warga Negara bersamaan kedudukannya di dengan hukum dan pemerintahan dan wajib menjunjung hukum dan pemerintahan tanpa terkecuali“. Keberadaan pasal 7 ayat (1) ini telah membuat perlakuan yang diskriminatif orang tua terhadap anak perempuannya dengan memaksakan mereka menikah dengan umur yang masih anak anak.

Suatu perbuatan dikategorikan diskriminatif menurut berbagai instrumen hukum Internasional hak asasi manusia yang diakui; setiap bentuk pembedaan, tidak memasukkan atau exclusion, pembatasan atau preferensi yang didasarkan pada alasan seperti ras, warna kulit, kelamin, bahasa, agama, pandangan politik dan pandangan lain, asal rumpun bangsa atau asal sosial dan lainnya yang mengakibatkan penghilangan kesetaraan dalam hak dan kewajiban. Lebih lanjut, untuk memperkuat alasan perlunya perubahan aturan hukum mengenai usia perkawinan, para pemohon menyatakan bahwa perkawinan yang dilaksanakan pada usia umur yang dini tidak sesuai dengan tujuan perkawinan, sebagaimana yang tertuang dalam penjelasan UU No. 1 tahun 1974 angka 4 huruf a dan $d$. Penjelasan mengenai tujuan perkawinan ini menyatakan bahwa perkawinan bertujuan membentuk keluarga yang bahagia dan kekal. Untuk itu suami isteri perlu saling membantu dan melengkapi agar masing- masing dapat mengembangkan kepribadiannya membantu dan mencapai kesejahteraan spiritual dan material. Lebih dari itu, poin (d) dari aturan penjelas ini menegaskan bahwa calon suami istri itu harus telah masak jiwa raganya untuk dapat melangsungkan perkawinan, supaya dapat mewujudkan tujuan perkawinan secara baik tanpa berakhir pada perceraian dan mendapat keturunan yang baik dan sehat. Untuk itu harus dicegah adanya perkawinan di antara calon suami isteri yang di bawah umur." 
Para pemohon juga mengajukan alasan personal yang mereka alami dan rasakan sebagai pelaku nikah bawah umur. Akibat perkawinan dini yang dipaksakan terhadap mereka, mereka mengalami berbagai persoalan, mulai dalam kehidupan mereka mulai dari persoalan akses pendidikan, buruknya kondisi ekonomi dan masalah kesehatan reproduksi. Mereka dipaksa untuk berhenti dari sekolah, padahal sebagai warga Negara mereka berhak mendapatkan pendidikan yang baik, wajib belajar Sembilan tahun. Dari segi ekonomi, mereka mempunyai akses ekonomi yang terbatas akibat keterbatasan pendidikan yang mereka dapatkan. Karena pendidikan yang rendah, mereka tidak bisa mencari nafkah secara memadai. Mereka Menggantungkan hidup mereka pada suami. Hal ini berakibat suami mendominasi dalam keluarga yang berujung pada tindakan kekerasan dalam rumah tangga yang dilakukan oleh suami. Lebih dari itu, dari segi kesehatan, mereka juga mengalami berbagai masalah kesehatan (reproduksi) seperti menderita infeksi reproduksi karena organ kelamin dan reproduksinya masih belum matang, dan keguguran pada kehamilan umur di bawah 19 tahun dan lemahnya kondisi anak yang dilahirkan.

Dalam Putusan MK No. 22/PUU-XV/2017 ini MK mengabulkan permohonan uji materi. Mahkamah konstitusi dalam putusannya mengambil keputusan memberikan pertimbangan bahwa berdasarkan penjelasan UU No. 1 tahun 1974 angka 4 huruf (d) yang menganut prinsip bahwa calon suami istri itu harus telah masak jiwa raganya untuk dapat melangsungkan perkawinan, maka perkawinan anak merupakan sesuatu yang dilarang. Selain itu, MK juga mendasarkan bahwa terjadinya perkawinan yang dialami oleh para pemohon tidak sesuai dengan pasal 13 dan Pasal 16 ayat (1) UU No. 23 tahun 2002 Tentang Perlindungan Anak. Pasal 13 ayat (1) menyatakan bahwa selama dalam pengasuhan orang tua, anak harus dilindungi dari perlakuan diskriminatif, eksploitatif, kekejaman, ketidakadilan, dan perilaku salah yang lain.23 Sedangkan pasal 16 ayat (1) menyatakan bahwa orang tua bukan hanya bertanggung jawab untuk mengasuh, memelihara, mendidik dan melindungi anak, menumbuhkembangkan anak, bakat dan minatnya, tetapi juga berkewajiban mencegah perkawinan anak". Dalam bagian selanjutnya, MK menyatakan bahwa agar tidak terjadi pelanggaran terhadap hak-hak anak, serta menghilangkan ketidakpastian hukum akibat ketentuan minimal dalam usia perkawinan yang disebutkan pasal 7 ayat (1) UU no. 1 tahun 1974, maka ketentuan mengenai usia perkawinan diubah menjadi 18 tahun sesuai dengan UU Perlindungan Anak. MK Juga menyatakan bahwa pasal 7 ayat (1) sepanjang frasa "usia 16 (enam belas) tahun" Undang-undang nomor 1 tahun 1974 tentang perkawinan bertentangan dengan Undang- undang dasar Negara Republik Indonesia tahun 1945 dan tidak mempunyai kekuatan hukum mengikat.

\section{Efektivitas Pasca Putusan Mahkamah Konstitusi Perihal Batas Usia Minimal Menikah Bagi Perempuan dan Pertimbangan Dalam Nilai-Nilai Hak Asasi Manusia}

Perkawinan merupakan hubungan hukum antara seorang laki-laki dengan seorang perempuan untuk hidup bersama dengan kekal, yang diakui oleh negara. Sehingga hubungan tersebut bersifat abadi. Apabila merujuk pada ketentuan undang-undang perkawinan, yang dimaksud dengan perkawinan adalah: ikatan lahir batin antara seorang pria dan wanita sebagai suami istri dengan tujuan membentuk keluarga (rumah tangga) yang bahagia dan kekal berdasarkan Ketuhanan Yang Maha Esa." Makna kalimat "ikatan lahir batin" disini, dimaksudkan hubungan sebagai satu kesatuan dan tidak dapat dipisahkan, adanya kewajiban terpenuhinya kedua- dua unsur tersebut. Ikatan lahir sebagai ikatan konkret atau hubungan formal yang dapat dilihat melalui bersikap, bertindak, berbuat dan bertingkah laku melalui kehidupan berumah tangga sebagai suami istri. Melalui hubungan formal ini masing-masing pihak memiliki peran dan tanggungjawab bagi dirinya maupun bagi orang lain atau masyarakat. Sedangkan makna kalimat: "ikatan batin" dimaksudkan adanya hubungan yang bersifat abstrak yang tidak dapat dilihat yang menjadi dasar 
atau pondasi bagi ikatan batin tersebut. Tanpa adanya ikatan batin, maka ikatan lahir akan menjadi rapuh.

Pasal 2 ayat (1) UU Perkawinan menegaskan kembali bahwa syarat sah perkawinan apabila dilakukan menurut hukum masing- masing agamanya dan kepercayaannya itu. Dengan demikian hakekat perkawinan tersebut bukanlah sekadar perjanjian, melainkan ikatan lahir batin yang keabsahannya didasarkan kepada hukum agama. Ikatan lahir batin antara suami dan istri hukum Islam diawali dengan adanya akad (,aqd) yaitu dengan adanya ijab dan qabul perkawinan. Perkawinan mensyaratkan harus didasarkan suka sama suka atau yang disebut dengan istilah persetujuan kedua belah pihak. Selain itu hukum positif menyatakan: perkawinan hanya diizinkan jika pria sudah mencapai umur 19 (sembilan belas) tahun dan pihak wanita sudah mencapai 16 (enam belas) tahun. Dalam hal terjadinya penyimpangan atau pengecualian dapat meminta dispensasi kepada pengadilan dan pejabat lain yang ditunjuk oleh kedua orang tua pihak pria maupun wanita. Ketentuan usia perkawinan tersebut berdasarkan pertimbangan kemaslahatan keluarga dan rumah tangga, sehingga yang diharapkan para pihak memiliki kematangan fisik dan psikis yang dapat mewujudkan tujuan perkawinan itu sendiri.

\section{Fenomena Pernikahan Usia Anak}

Pernikahan di usia anak ini kembali menjadi sorotan publik dalam lingkup dunia internasional, dibuktikan dengan tingginya tingkat pernikahan usia anak di belahan dunia. Berdasarkan hasil data UNICEF bahwa: ada 115 juta anak menikah dibawah umur, berdasarkan data populasi di 82 (delapan puluh dua) negara. Melalui UNICEF sebagai lembaga pemerhati anak menghimbau pentingnya kesadaran untuk memperjuangkan hak-hak sipil anak sebagai hak dasar atau hak asasi dalam bentuk gerakan solidaritas sebagaimana ditegaskan dalam Deklarasi Universal Hak Asasi Manusia (Universal Declaration of Human Rights), Konvensi Hak-hak Anak Perserikatan BangsaBangsa (United Nations Convention on the Rights of the Child) yang mengatur hak-hak sipi, politik, ekonomi, sosial, dan kultural anak-anak, dan Konvensi tentang penghapusan segala bentuk diskriminasi terhadap perempuan (Convention on the Elimination of all Forms of Discrimination Against Women/ CEDAW). Ajakan ini dengan menggaungkan semboyan: "Jangan Biarkan AnakAnak Mempunyai Anak".

Mies Grijns (seorang antropolog), dalam diskusi bertajuk "Child, Early, and and Counter Measures". Yang dilaksanakan oleh Pusat Kajian Antropologi Universitas Indonesia dan Leiden University, pada tanggal 9 Maret 2018, berdasarkan hasil risetnya di di kawasan Sukabumi sejak 2014 hingga 2017 menyatakan bahwa pernikahan anak cenderung dilatarbelakangi dengan alasan suka sama suka, keinginan menghindari kekerasan rumah tangga yang melibatkan orang tua, karena ditelantarkan atau ditinggalkan oleh orang tua yang bekerja keluar kota atau keluar negeri. Pemenuhan hi hidup mencakup materi atau sosial.

Pernikahan usia anak tidak hanya terjadi di masyarakat pedesaan tetapi juga merambah ke Perkotaan hal ini berdasarkan survei sosial ekonomi pada tahun 2018 yang menyatakan bahwa $13,6 \%$ perempuan di Indonesia mencapai usia 20 tahun sampai 24 tahun saat di survei telah menikah di bawah usia 18 tahun dan masih mempertahankan rumah tangganya. Sementara data pernikahan perempuan di bawah usia 18 tahun yang sudah bercerai mencapai $24,17 \%$. Jumlah ini cukup tinggi, jika melihat dari data UNICEF 201 yang menempatkan Indonesia sebagai negara dengan peringkat ketujuh dalam hal pernikahan anak di dunia. Kemudian, berdasarkan hasil data susenas 2015 di daerah Sulawesi Tengah. Rata-rata anak berusia 15-19 tahun berstatus menikah dan pernah menikah, yang terdapat di Kabupaten Banggal Laut sevesar 15.83\%, Kabupaten Banggal kepulauan 15.73\%, Kabupaten Sigi 13.77\%, Kabupaten Tojo Una-Una $12.84 \%$ dan Kota 
Palu $6.90 \%$. Usia perkawinan di sulawesi tengah mencapai $20.19 \%{ }^{19}$. Lebih dari 700 juta perempuan ketika menikah masih anak- anak dan satu dari tiga diantaranya menikah sebelum usia 15 tahun. Anak- anak perempuan yang menikah muda, akan menghadapi akibat buruk diantaranya: (1). Rendahnya tingkat pendidikan; (2). Akibat buruk terhadap kesehatan seksual dan reproduksi; (3). Peningkatan tingkat kekerasan dalam rumah tangga. Misalnya, terkait dengan tingkat pendidikan, rata-rata anak perempuan di Indonesia yang menikah sebelum usia 18 tahun cenderung akan memilih tidak melanjutkan sekolah. Sehingga persentase perkawinan usia anak perempuan yang lulus SD mencapai 40,5 \% Berdasarkan data Badan Pusat Statistik pada Tahun 2017, sebaran angka perkawinan anak berada diatas 25\% di 23 Provinsi dari 34 Provinsi yang di survei. Hal ini dapat dilihat pada Diagram I di bawah ini:

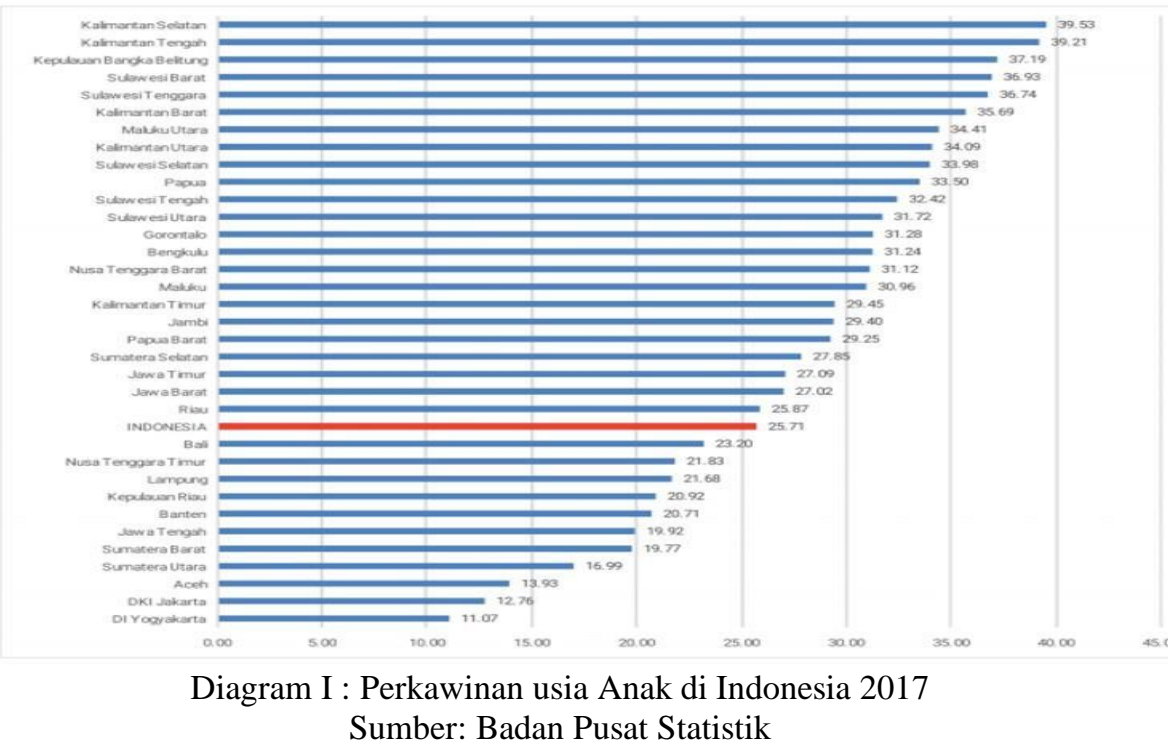

Perkembangan hak asasi manusia oleh Karel Vasak (ahli hukum Perancis) membagi menjadi 3 (tiga) negerasi yaitu Generasi pertama : perjuangan terhadap hak Sipil dan Politik dengan slogan kebebasan (freedom of) yang dituangkan dalam International Covenant on Civil and Political Right (ICCPR) atau disebut dengan Kovenan Internasional tentang Hak Sipil dan Politik (Hak SIPOL). Hak-hak ini pada hakikatnya melindungi, menghormati kehidupan pribadi manusia sebagai manusia otonom.

Generasi kedua: Perjuangan terhadap hak ekonomi, sosial, dan budaya dengan menggunakan slogan "persamaan" sehingga dalam pemenuhan hak tersebut tidak lagi menggunakan istilah "freedom of" akan tetapi menggaungkan istilah "right to" (hak atas). Hak-hak ini dituangkan dalam International Covenant on Economic, Social and Cultural Rights (ICESCR) atau disebut dengan Kovenan Internasional tentang Hak-Hak Ekonomi, Sosial dan Budaya (EKOSOB). Misalnya pemenuhan terhadap hak atas pendidikan, dalam hal ini negara telah mencanangkan program pendidikan wajib belajar 9 tahun. Melalui program ini setiap anak (usia 7 sampai dengan usia 15 tahun) wajib memperoleh perlindungan dalam menuntaskan pendidikan 9 tahun.

Generasi Ketiga: merupakan bentuk perjuangan untuk mengkonseptualisasikan kembali tuntutan terhadap pemenuhan hak sipil, politik, ekonomi, sosial, dan budaya. Sehingga generasi ini lebih memfokuskan pada gerakan "persaudaraan" atau "hak solidaritas" atau "hak bersama" yang menginginkan terciptanya suatu tatanan ekonomi atas hukum internasional yang adil. Seperti: hak atas perdamaian; hak atas sumber daya alam sendiri; hak atas lingkungan hidup yang baik; dan 
hak atas warisan budaya sendiri. Perlindungan hak berkeluarga dalam hukum hak asasi manusia misalnya, sebagai salah satu hak sipil, telah memberikan jaminan perlindungan melalui ketentuan artikel 16 DUHAM dan artikel 23 Kovenan hak SIPOL Artikel 16 DUHAM

Berdasarkan artikel 16 DUHAM dan artikel 23 Kovenan Sipol, perlindungan hak berkeluarga, mensyaratkan: laki-laki dan perempuan yang sudah dewasa, berdasarkan pilihan bebas dan persetujuan penuh oleh kedua- nya, tidak dibatasi kebangsaan, kewarganegaraan atau agama, dengan memiliki hak yang sama baik dalam soal perkawinan, di dalam masa perkawinan dan di saat perceraian. Dengan dijadikannya DUHAM sebagai standar umum yang bersifat universal, maka disyaratkan bagi negara-negara anggota untuk mengimplementasikannya ke dalam ketentuan hukum nasional negaranya masing-masing, dengan memperhatikan nilai-nilai budaya negara masing-masing. Akan tetapi, apabila dalam penerapan HAM ditemukan pertentangan antar keduanya, maka yang lebih diutamakan adalah nilai-nilai HAM.

\section{KESIMPULAN DAN SARAN}

Berdasarkan uraian di atas dapat disimpulkan, pertama Pasal 7 ayat (1) UU Perkawinan dianggap bertentangan dengan pasal 27 ayat (1) UUD Tahun 1945 tentang kesamaan hak dan kedudukan semua warga Negara. Dalam pertimbangannya Putusan MK tersebut merupakan sebuah putusan yang tidak hanya memberikan rasa keadilan bagi para pemohon yang merasa telah mendapatkan tindakan diskriminatif sebagai warga Negara dan pun bagi para pemohon pada perkara putusan No. 33-74/PUU-XII/2014 yang berjuang untuk meniadakan perkawinan dini. Lebih dari itu, putusan tersebut juga membawa kemaslahatan pada seluruh masyarakat Indonesia berupa kesetaraan laki-laki dan perempuan di depan hukum sekaligus kemaslahatan bagi calon mempelai dalam bidang kognitif (cara berpikir), psikologis, biologis, maupun ekonomi. Putusan tersebut memberikan jaminan yang lebih baik bagi kematangan calon mempelai dari berbagai bidang tersebut. Dari perspektif normatif hukum Islam, kemaslahatan ini juga sesuai dengan tujuan dari syari'at Islam yang bertujuan untuk merealisasikan kemaslahatan dan menghindarkan kemudharatan. Dalam konteks ini, kemaslahatan yang dimaksud adalah usaha yang lebih baik dalam menyelamatkan lembaga perkawinan sebagai lembaga yang mulia sebagai pelaksanaan perintah agama dan ketentuan Negara dengan meningkatkan batas usia perkawinan bagi perempuan.

Kedua, efektivitas pasca-putusan Mahkamah Konstitusi dapat dilihat bahwa dengan adanya penetapan usia minimal menikah bagi perempuan 19 (sembilan belas) tahun sangat sarat akan nilai-nilai hak asasi manusia, sebagai salah satu bentuk kesadaran masyarakat dan tanggung jawab negara atas perlindungan dan pemenuhan terhadap hak-hak anak, prinsip non diskriminasi, dan hak konstitusi. Persoalan melihat kedepan dampak dari perkawinan usia anak bagi perempuan dapat menimbulkan tindakan diskriminasi terhadap perempuan terkait dengan persoalan kedudukan hukum antara laki- laki dan perempuan dan terjadinya pelanggaran terhadap hak-hak anak. Dengan ditetapkannya batas usia minimal menikah 19 (sembilan belas) tahun bagi perempuan, diharapkan kepada Pemerintah Daerah agar bersinergi dengan LSM dan lembagalembaga swadaya lainnya yang ada di daerah untuk sosialisasi dalam memberikan penyuluhan kepada masyarakat (orang tua, pemuka agama, dan stakeholders yang ada) di desa-desa akan pentingnya kesadaran melindungi pemenuhan terhadap hak-hak anak dan pemahaman prinsip non diskriminasi terhadap anak (perempuan) dengan cara pencegahan terjadinya perkawinan usia anak. Ketiga, berdasarkan data yang didapatkan juga menunjukan bahwa tingginya fenomena pernikahan usia anak tidak hanya menjadi momok permasalahan yang menakutkan di Indonesia namun juga dunia dalam skala internasional. Hal ini dibuktikan dengan hasil data UNICEF bahwa ada 115 juta anak menikah dibawah umur, berdasarkan data populasi di 82 (delapan puluh dua) 
negara. Tingginya tingkat perkawinan usia anak di Indonesia dapat terlihat dari data UNICEF yang menempatkan Indonesia sebagai negara dengan peringkat ketujuh dalam hal pernikahan anak. Dengan adanya angka-angka perkawinan dibawah umur yang begitu besar, maka sudah selayaknya kita semua berbuat untuk menahan laju peningkatan pernikahan dibawah umur. Untuk menekan peningkatan pernikahan dibawah umur perlu kesadaran masyarakat akan dampak yang terjadi akibat pernikahan dibawah umur, sebaiknya pihak pemerintah terkait lebih meningkatkan kerjasama untuk memberikan kesedaran masyarakat tersebut, adapun upaya yang harus dilakukan untuk memberikan kesadaran masyarakat akan dampak pernikahan dibawah umur yaitu dengan membentuk sebuah program nasional pemerintah untuk memberikan kesadaran kepada masyarakat, seperti membentuk instansi atau team khusus yang langsung turun kelapangan untuk memberikan penyuluhan akan dampak bahaya pernikahan dibawah umur. Hal ini dilakukan terutama di daerah daerah pedesaan yang relatif masih banyak terjadi pernikahan dibawah umur.

\section{Ucapan Terima Kasih (Acknowledgement)}

Kami mengucapkan terimakasih kepada Lembaga Penelitian dan Pengabdian kepada Masyarakat (LPPM) Universitas Tarumanagara Kantor Urusan Agama Bandung, Kantor Urusan Agama Malang, Pengadilan Agama Negeri Bandung, Pengadilan Agama Malang, Pengadilan Agama Bandung, Pengadilan Negeri Malang, dan Pengadilan Negeri Bandung.

\section{REFERENSI}

Afriani, R. (2016). Analisis dampak pernikahan dini pada remaja putri di Sidoluhur kecamatan Godean Yogyakarta. Rakernas Aipkema.

Anonim. (2017). Mengenal tradisi balawang tujuh, perkawinan janda duda. Okezone.com. https://lifestyle.okezone.com/read/2017/11/29/196/1822273/mengenal-tradisi-balawangtujuh-perkawinan-janda-duda.

Arikunto, S. (1993). Prosedur penelitian suatu pendekatan praktek. Ed. Revisi II. Rineka Cipta.

Badan Pusat Statistik. (2015). Perkawinan usia anak di Indonesia. UNICEF-Indonesia

Darwin, M. 2018. Kesehatan reproduksi: Ruang lingkup dan kompleksitas masalah. Jurnal Populasi.

Djamilah. (2014). Dampak perkawinan anak di Indonesia. Jurnal Studi Pemuda.

Kitab Undang-Undang Hukum Perdata (KUHHPerdata)

Kompilasi Hukum Islam

Kumar, R. (1999). Research methodology: A step-by-step guide for beginners. Addison Wedley Longman Australia Pty. Limited.

Mayadina, R. M. (2016). Pernikahan dini dan upaya perlindungan anak di Indonesia. Jurnal Hukum dan Syariah.

Mubasyaroh. (2016). Analisis faktor penyebab pernikahan dini dan dampaknya bagi pelakunya. Jurnal Pemikiran dan Penelitian Sosial Keagamaan.

Nurudi, A. (2004). Hukum Perdata Islam di Indonesia. Kencana.

Rahmah, M. (2015). Psikoedukasi tentang resiko perkawinan usia muda untuk menurunkan intensi pernikahan dini pada remaja. Jurnal Intervensi Psikologi

Soekanto, S. (1981). Pengantar penelitian hukum, Cetakan ke-2, Universitas Indonesia Press

Sumardjono, M. S. W. (1989). Pedoman pembuatan usulan penelitian. PT. Gramedia

Tim Hukum Online. (2018). Akta nikah dini di bantaeng: Meski diizinkan orang tua, sebenarnya bisa saja dicegah. hukumonline.com https://www.hukumonline.com/berita/baca/lt5b92592652c28/fakta-nikah-dini-dibantaeng--meski-diizinkan-orang-tua--sebenarnya-bisa-saja-dicegah.

Undang-Undang Dasar Republik Indonesia 1945.

Undang-Undang Republik Indonesia Nomor 1 Tahun 1974 tentang Perkawinan 
Undang-Undang Republik Indonesia Nomor 48 Tahun 2009 tentang Kekuasaan Kehakiman

Undang-Undang Republik Indonesia Nomor 35 Tahun 2014 atas Perubahan Undang-Undang Nomor 23 Tahun 2002 tentang Perlindungan Anak

Zulfiani. (2017). Kajian hukum terhadap perkawinan anak dibawah umur menurut UndangUndang Nomor 1 Tahun 1973. Jurnal Hukum Samudra Keadilan. 